\section{O roślinnej historii miasta z perspektywy jego mieszkańca}

Clara Zgoła
Projekt zostałsfinansowany ze środków Narodowego Centrum Nauki przyznanych na podstawie decyzji nr DEC-2017/24/T/ $\mathrm{HS}_{2} / 00064$.

Wspominamy o nich od niechcenia, ich nazwy nam umykają. Filozofia od zawsze je zaniedbywała, raczej z powodu pogardy niż przeoczenia. Stanowią kosmiczną ozdobę, nieistotny, kolorowy przypadek zaprzątający marginesy naszego namysłu. Współczesne metropolie uznają je za nadmiarowe bibeloty, element miejskiej dekoracji. Poza murami miast przypada im, czyli chwastom, rola gospodarzy lub przedmiotów masowego przemysłu. Rośliny są zawsze otwartą raną metafizycznego snobizmu, który definiuje naszą kulturę. ${ }^{1}$

Co ciekawe, ta ogólna uwaga odnosi się także do marginalnego znaczenia nadawanego roślinom w kontekście

Clara Zgoła - mgr, doktorantka CRAL CNRS-EHESS/ IKP UW, badaczka stowarzyszona OKF UW. Zajmuje się współczesną kulturą francuską i badaniami miejskimi. Kierowniczka projektów badawczych „Paryskie tożsamości współczesnych powieściopisarzy francuskich", „Literackie praktykowanie miasta" (NCN Preludium/Etiuda), „Writings from the Archives."Współredaktorka tomów Foucault: źródła// ujścia (2015) i Cultures en marges (2018).

1 E. Coccia La vie des plantes. Une métaphysique du mélange, Payot \& Rivages, Paris 2016, s. 15 [wszystkie cytaty z języka francuskiego w przekładzie własnym - C.Z.] 
miejskim, podkreśla bowiem dwojakość przypisywanego im statusu: z jednej strony chodzi o ich walor dekoracyjny, wykorzystywany chociażby przez architektów pejzażu i urbanistów, z drugiej natomiast o rolę intruza zakłócającego porządek zielonej infrastruktury. Podobną prawidłowość możemy obserwować w odniesieniu do autobiograficznie nacechowanej prozy będącej przedmiotem niniejszej analizy. Istotnie, w polu percepcji autorów znajdują się zarówno historycznie i społecznie usankcjonowane sposoby organizacji miejskiej zieleni, czyli tzw. formy zwarte, w postaci chociażby ogrodów czy parków, jak i formy swobodne, zwłaszcza „roślinność spontaniczna”, czyli chwasty. W przeciwieństwie do tej, która stanowi część uładzonego pejzażu miejskiego, roślinność niepodlegająca profesjonalnej interwencji, samorzutna i ekspansywna, odpowiada zwykle terenom obrzeżnym, niezagospodarowanym, a nawet niepodatnym na zmapowanie. Obydwu typom interakcji z roślinnym środowiskiem towarzyszy zatem odrębny zasób praktyk miejskich, a także literackich sposobów ich obrazowania.

Refleksja nad tym, w jaki sposób flora miasta współtworzy jego materialny, a także kulturowo-społeczny charakter, cieszy się długą, częściowo zapoznaną tradycją. Za jej szczególne rozwinięcie można uznać twórczość pisarzy sytuujących swoje rozmyślania na pograniczu nauk społecznych lub humanistycznych i prozy eseistyczno-autobiograficznej. W niniejszym artykule zamierzam przyjrzeć się relacjom między sprawczością roślin w minionym stuleciu i XXI wieku a strategiami narracji na temat kulturowej historii miasta. Wychodząc od XX-wiecznego i XXI-wiecznego Paryża rozpatrywanego w kontekście autobiograficznej prozy autorstwa Claude'a Eveno (L'humeur paysagère), Alexandre'a Lacroix (Voyage au centre de Paris) i Philippe'a Vasseta (Un livre blanc), czerpiąc równocześnie z propozycji teoretycznych botanika Petera Del Tredici (rośliność kosmopolityczna), architekta pejzażu i pisarza Gilles'a Clémenta (trzeci pejzaż) i geografa Bradleya L. Garretta (miejska eksploracja), pragnę przyjrzeć się roślinnej szacie tego miasta, jej uwikłaniu w historię - na przykładzie okupacji niemieckiej, kulturowej rewolucji Maja 1968 roku, przemian postindustrialnych - a nade wszystko różnorodnym praktykom miejskim i ich literackim przekształceniom, pozwalającym nam lepiej uchwycić ten wieloaspektowy związek.

\section{Mieszczanin w ogrodzie}

Warto przypomnieć, że historia nowoczesnej, XIX-wiecznej, zielonej infrastruktury Paryża pokrywa się z latami panowania Napoleona III, który 
z okresu wygnania wyniósł także zainteresowanie londyńskimi parkami. W istocie, zakrojona na szeroką skalę modernizacja francuskiej stolicy doby II Cesarstwa, zwana także jej „haussmanizacją”, stworzyła podwaliny jej dzisiejszego ekosystemu (jego cztery zasadnicze filary to parki, ogrody, laski i skwery) opartego w dużej mierze na konfiguracji symetrycznie rozmieszczonych, zielonych płuc: położonego na zachodzie Lasku Bulońskiego, na wschodzie Lasku Vincennes, i dwu nowo utworzonych wówczas parków o nieco skromniejszych rozmiarach - Buttes-Chaumont na północy i Montsouris na południu². Tym samym nowocześnie zaprojektowane przestrzenie zielone, wywodzące się zwykle z dawnych królewskich obszarów łowieckich lub arystokratycznych wilegiatur, w szóstej i siódmej dekadzie XIX wieku zostały otwarte dla szerokiej publiczności. Nie należy jednak zapominać, że społecznie usankcjonowane sposoby korzystania z tych enklaw dawały pierwszeństwo uprzywilejowanym, zasobnym mieszkańcom Paryża i choć miasto zazieleniło się za sprawą upiększonych szpalerami drzew przestronnych alei, a także ogólnie dostępnych skwerów, to fatalne warunki mieszkaniowe ubogiej ludności pozbawionej możliwości obcowania z fantazyjnie zaaranżowaną zielenią nie zmieniły się zasadniczo w tym okresie ${ }^{3}$.

Za paradygmatyczny przykład organizacji tej poniekąd ekskluzywnej formy miejskiej zieleni można uznać ogród, którego nazwa wywodzi się od germańskiego garto (niem. garten) i jednoznacznie wskazuje na definiujący charakter ogrodzenia. Z antropologiczno-historycznej perspektywy miasto i ogród lub park wywodzą się z podobnego gestu: wydzielenia, wyznaczenia granicy, a także odseparowania. Zieleń miejska - wymagająca poskromienia, ujęcia w karby i funkcjonalizacji - jest zarazem nośnikiem pewnej tęsknoty (za tym, co utracone) i obawy (nakazującej ograniczenie jej sprawczości),

2 F. Choay Haussmann et le système des espaces verts parisiens, "Revue de l'Art" 1975 No. 29, s. 83-99. Baron Haussmann, któremu powierzono przebudowę Paryża, miał swojego nieco zapomnianego odpowiednika odpowiedzialnego za zieloną infrastrukturę, był nim Jean-Charles Adolphe Alphand. Cesarz natomiast przedstawił własne szkice dotyczące organizacji lasków i parków wzorowane m.in. na londyńskim Hyde Parku.

3 S. Lefay Le jardin pittoresque entre ouverture et exclusion: les paradoxes de l'intimité, w: Jardins et intimité dans la littérature européenne (1750-1920), dir. S. Bernard-Griffiths, F. Le Borgne, D. Madelénat, PUBP, Clermont-Ferrand 2008, s. 41-53. Obecność w laskach pełniła funkcję nobilitującą, to w nich należało bywać, a raczej pokazywać się w pełnej krasie, natomiast możliwość skorzystania z krzesła w parkach do drugiej połowy ubiegłego wieku wiązała się z koniecznością uiszczenia opłaty. 
zupełnie jakby roślinność przywodziła na myśl wieś, a zatem nie-miasto, element do pewnego stopnia obcy lub nawet groźny, prawie zawsze zaś gorzej wartościowany. Uprzedmiotowiające podejście do flory, czy też szczerzej natury, wyrastające z antropocentrycznych przesłanek filozoficznych, zgodnie z którymi natura pełni rolę służebną, osiągnęło swój paroksyzm we francuskim ogrodnictwie doby André Le Nôtre'a, kładącym szczególny nacisk na ozdobność i regularność kompozycji ${ }^{4}$. Co ważne, przetrwało ono upadek monarchizmu i na trwale zaważyło na stosunku do - nie tylko miejskiej - roślinności.

Ogród to także, jak dobrze wiemy, wyeksploatowany motyw literacki, miejsce bukoliczne (Arkadia, Eden), a zarazem chronotop denotujący w okresie romantyzmu koncepcje egalitarne i utopijne. O ile jednak topos klasycznego ogrodu wiązał się raczej z harmonią, ładem, wreszcie zdrowiem i odnową (za sprawą uzdrawiających właściwości roślin, w tym zwłaszcza ziół), o tyle ogród dekadencki zyskał złowrogi wymiar - symbolizował wynaturzenie, generował matrycę wyobrażeń erotycznych. Zarówno w prozie, jak i w sztuce użytkowej końca XIX i początku XX wieku na pierwszy plan wysunięto budzące fascynację gatunki patogenne, niecodzienne, egzotyczne, ich łacińskie nazwy przywodziły na myśl rzadkie choroby ${ }^{5}$. Nie bez znaczenia był tu również nowy porządek miejskich praktyk kulturowych, których celem było okiełznanie i poskromienie roślinnego żywiołu. Mieszczanie, zwłaszcza przedstawiciele burżuazji, upodobali sobie wycieczki do ogrodu botanicznego, arboretum, stanowiących nieodłączną część wystaw światowych, oranżerii. Popularnością cieszyły się ogrody zimowe, a także ogrodowe szklarnie. Ich na wskroś sztuczny, ostentacyjnie zamknięty i duszny charakter odpowiadał zarówno wyobrażeniu na temat idealnie urządzonego wnętrza, jak i nade wszystko scjentystycznej idei laboratorium, a zarazem kolonialnej kartografii świata fauny i flory. Obcowanie z roślinami nabrało waloru edukacyjnego, poznawczo wzbogacającego, przy

4 Histoire des jardins de la Renaissance à nos jours, dir. M. Mosser, G. Teyssot, Flammarion, Paris 1991.

5 G. Sicotte Le jardin dans la littérature fin-de-siècle, ou quand un motif narratif devient un objet esthétique, „Projets de Paysage Revue scientifique sur la conception et l'aménagement de l'espace" 2011, http://www.projetsdepaysage.fr/editpdf.php?texte=621 ( 15.11.2017). Podręcznikowego przykładu zestetyzowanej fascynacji naturą, przekładającej się na styl sztuki dostarcza secesja. Sztuka współczesna, zwłaszcza bioart, wchodzi w głębsze interakcje ze światem roślinnym, zob. M. Bakke Bio-transfiguracje. Sztuka i estetyka posthumanizmu, Wydawnictwo Naukowe UAM, Poznań 2015. 
czym udoskonalana od czasów Linneusza taksonomia działała równocześnie niczym narzędzie wiedzy i władzy ${ }^{6}$.

Na przeciwległym biegunie utylitarnych użytków, którym podporządkowywano miejską roślinność, a zarazem w odniesieniu do odrębnych grup społecznych, sytuowały się dydaktycznie zabarwione projekty dotyczące ogrodów jako przestrzeni kształcenia najmłodszych i poprawy jakości życia robotników. Rodzimym przykładem byłyby dobrze znane ogródki jordanowskie oraz tzw. ogrody Raua zakładane na terenach miast pod zaborami, przeznaczone zaś dla dzieci i młodzieży. Nieco wcześniej (dokładnie trzy dekady) od Henryka Jordana podobny pomysł wysunął inny lekarz-społecznik, Moritz Schreber (stąd Schreberplatz oraz Schrebergarten). Idea ogródków robotniczych, znanych jako miejskie ogródki działkowe, sięgająca korzeniami rewolucji przemysłowej w Wielkiej Brytanii, przyjęła się i we Francji. W efekcie w przededniu I wojny światowej region paryski liczył ponad tysiąc pięćset takich parceli, z których połowa znajdowała się na przedmieściach ${ }^{7}$. Ten w pewnym stopniu podrzędny wymiar przestrzenny i klasowy pozostanie ich cechą charakterystyczną. Do dziś można zauważyć znaczące różnice w rozmieszczeniu terenów zielonych, a także ich dostępności: podczas gdy zachodnie, zamożne obrzeża miasta sąsiadują z niegdysiejszymi parkami królewskimi, rogatki północne i wschodnie pozbawione są podobnego kontaktu. Nie dziwi zatem fakt, że to właśnie tam najsilniej rozwinęło się oddolne i kolektywne ogrodnictwo. Podczas gdy na mieszkańca regionu Seine-Saint-Denis przypadają dwa metry kwadratowe zieleni, ten sam współczynnik w odniesieniu do regionu Hauts-de-Seine osiąga ponad dziesięciokrotnie wyższą wartośśc ${ }^{8}$. Tym samym możliwość wchodzenia w interakcję z miejską florą pozostaje przywilejem, a poszczególne praktyki zdają się znamionować przynależność do określonej grupy społecznej.

6 M. Cettou Jardins d'hiver et de papier: de quelques lectures et (ré)écritures fin-de-siècle , A Contrario" 2009 No. 1, s. 99-117.

7 Cent ans d'histoire des jardins ouvriers 1896-1996. La Ligue française du coin de terre et du foyer, dir. B. Cabedoce, P. Pierson, Éditions Créaphis, Paris 1996. W literaturze przedmiotu rodzinne bądź miejskie ogródki działkowe figurują pod kilkoma nazwami, wśród których wyliczyć można następujące: jardins ouvriers/associatifs/communautaires, partagés, familiaux, collectifs.

8 D. Franck "Pas de parcs pour Paris?”, "Bulletin de l'Association de géographes français” 1989 No. 3, s. 185-191.

9 W przeciwieństwie do kultury polskiej, w obrębie której miejskie ogródki działkowe zostały szeroko spopularyzowane, częściowo zatracając swój robotniczy rodowód, we francuskim kontekście pozostają nadal silnie naznaczone klasowo. Klasa średnia obcowanie z przyrodą łą- 


\section{Ogródki warzywne i ogrody pamięci}

O tym dwutorowym typie interakcji z miejską zielenią - zarazem jako przedmiocie uczonej, estetyzującej kontemplacji, jak i wernakularnych praktyk wspomina Claude Eveno, pisarz, wykładowca i reżyser, na co dzień zajmujący się urbanistyką i studiami nad pejzażem, autor książek L'humeur paysagère i Revoir Paris.Źródeł swoich zainteresowań dopatruje się właśnie w przebywaniu w rodzinnych ogrodach bądź w ich namiastkach: „Trudno o bardziej banalną czynność umysłową niż wspominanie ogrodu z własnego dzieciństwa. Nawet dzieci biedoty zamieszkującej paryskie przedmieścia korzystały ze strefy tak, jakby była prawdziwym ogrodem. Nie ulega wątpliwości, że wspomnienia z tego okresu były dla nich tak samo magiczne, jak te, które przywoływać mogli ich lepiej sytuowani rówieśnicy zamieszkujący wolnostojące domy z przyległym ogrodem ${ }^{10}$. Autobiograficznie zabarwiona narracja Eveno osadzona jest w kontekście historycznym, dzięki któremu zostaje stematyzowane doświadczenie pokoleniowe:

Inna, równie banalna myśl: przez długi okres miasto [Paryż - przyp. C.Z.] zamieszkiwane było przez dzieci przybyłe doń na fali wiejskiego exodusu, pierwsze pokolenie wewnętrznej emigracji, zachowujące związki z rodzimą wsią. Jestem jednym z nich, moją pamięcią rządzą wspomnienia ogródka bretońskiej prababki i tego [należącego do - przyp. C.Z.] praprababki pochodzącej z Chartres. W obydwu przypadkach chodziło o zwykle ogródki warzywne, lecz moje dziecięce spojrzenie nie dostrzegało owej przeciętności, czyniąc z nich miejsca ogromne i o bogatej roślinności, przepełnione niespodziankami, których doświadczałem przy okazji każdego z wakacyjnych pobytów."11

czy z wyjazdami na wakacje, a także pobytami w nabytych domach na wsi lub letniskowych (fr. résidence secondaire), stosunkowo słabo przyjął się popularny w innych krajach Zachodu nurt miejskiego ogrodnictwa związany ze zwrotem ekologicznym ostatnich dekad, zob. C. Blondy, L. Vacher, D. Vye Les résidents secondaires, des acteurs essentiels des systèmes touristiques littoraux français?, ,"Territoire en mouvement Revue de géographie et aménagement", http://journals.openedition.org/tem/3344 (25.11.2017).

C. Eveno L'humeur paysagère, Christian Bourgois, Paris 2015, s. 14. Strefa, inaczej zona (zone non aedificandi), to otaczający miasto pas ziemi szerokości 250 metrów, na którym nie wolno było stawiać budynków, w Paryżu powstała na skutek zburzenia dawnych fortyfikacji w połowie XIX wieku. Aż do jej stopniowej likwidacji w latach 20. XX wieku była gęsto zapełniona nielegalną, tymczasową zabudową wznoszoną przez najbiedniejszą ludność stolicy stanowiącą miejski proletariat. 
Ten element wydaje się szczególnie istotny, gdyż w pewnym stopniu stabuizowany i słabo obecny we współczesnych narracjach autobiograficznych osadzonych we francuskiej stolicy ${ }^{12}$. Narrator przywołuje z pamięci odwiedzane na różnych etapach życia ogrody odległych krajów, w tym także te, które są naznaczone intymnymi wspomnieniami (najczęściej paryskie lub podparyskie), jednak każdorazowo postrzega opisywany pejzaż przez pryzmat bogatych odniesień malarskich, filmowych, historycznych i literackich. Tym samym w jego konstrukcję zostaje wpisana inherentna dlań i nierozstrzygalna podwójność: to zarazem widok natury i przedstawienie tego widoku. Kluczem jest tu przetworzenie pierwotnego stanu natury przez człowieka i zapośredniczenie kulturowe, które pozwala uchwycić specyfikę tak pojmowanej przyrody. Jeśli zatem w krajobrazie się nie mieszka i dostarcza on innego, niecodziennego typu doświadczenia, to w istocie narrator przenosi postawę flâneura w przestrzeń otaczającej go zieleni: spacerując po miejskich parkach i ogrodach, kontempluje spektakl usztucznionej, ujarzmionej natury, a zarazem snuje opowieść osadzoną w rytmie eseistycznej, kunsztownie rozbudowanej frazy.

Z kolei warte dostrzeżania odstępstwo od tej reguły stanowi doświadczenie rodzinnych ogródków, które choć wyłamuje się z codzienności młodocianego paryżanina, opiera się właśnie na zwyczajności i prostocie tej formy obcowania z zielenią:

W Chartres zanurzałem się w innym świecie, ponieważ ogród mojej praprababki był ogródkiem warzywnym usytuowanym na przedmieściach i ten jego podmiejski rys - rys, którego sobie oczywiście wówczas nie uświadamiałem - odróżniał go od bretońskiego ogródka warzywnego. W rzeczywistości było w nim niewiele roślin, rządziły nim jednak te same zasady rozmieszczania sadzonek, tworzył znaczącą całość. ${ }^{13}$

W podmiejskich warzywnikach dochodzi bowiem do głosu bez mała magiczne myślenie o roślinach i ich relacjach z człowiekiem. Na pierwszy plan

Pisarze paryscy wywodzący się z innych regionów Francji wspominają o tym w swoich autobiogeografiach, por. B. Duteutre L'été 76, Gallimard, Paris 2011; P. Le Guillou Géographies de la mémoire, Gallimard, Paris 2016; C. Thomas Cafés de la mémoire, Seuil, Paris 2008, natomiast w przeciwieństwie do robotniczego, wiejskie pochodzenie sięgające więcej niż jednego pokolenia wstecz zostaje zwykle przemilczane. 
zostaje wysunięta zasada homologii różnych istnień,ich niewidocznych, lecz odczuwanych powiązań:

Żywot tego, co roślinne, jawił mi się jedynie pod postacią drzew owocowych, to w odniesieniu do nich, zwłaszcza - posadzonego w dniu moich urodzin i w celu uczczenia tej okazji - drzewka brzoskwiniowego, wyczekiwałem zbiorów. To drzewo było moim sobowtórem-bliźniakiem, w tamtym zabobonnym świecie obawiałem się umrzeć w tym samym czasie, co ono, i choć obawa ta okazała się nieuzasadniona, to jego uschnięcie - w kilka lat po śmierci mojej babki - gdy ogródek warzywny przekształcono w trawnik i już tylko ono przypominało mi o Edenie mojego dzieciństwa, pogrążyło mnie w prawdziwym smutku. ${ }^{14}$

Przywołany powyżej fragment to badaj jedyny moment, w którym narrator przezwycięża postawę kontemplatora i znawcy, by zwrócić uwagę na nieco nostalgicznie nacechowaną opowieść o bezpowrotnie utraconym poczuciu jedności z naturą, ulotnym stanie ujawniającym się w okresie dzieciństwa. Sposób, w jaki Eveno konstruuje obrazy kontaktu z florą miejską, nie odbiega bowiem od tradycji literackiej, każącej postrzegać tereny zielone, a zwłaszcza ogrody, jako loci pamięci lub niczym pretekst do ćwiczenia uwagi i biegłości w nazywaniu otaczającego nas świata. W podobnej perspektywie powyższa praktyka dyskursywna nie służy jednak pielęgnowaniu relacji opartej na współzależności, zdecydowanie bliżej jej do ujarzmienia.

\section{Kulturowa sprawczość roślin: wojenne paulownie i rewolucyjne pyłki}

Alexandre Lacroix jest zarówno dziennikarzem, jak i poczytnym powieściopisarzem. W książce Voyage au centre de Paris, składającej się z prawie pięćdziesięciu niewielkich rozdziałów odpowiadających poszczególnym adresom francuskiej stolicy, autor posiłkuje się biografią botaników: Williama Nylandera i Bouly'ego de Lesdain, aby nakreślić tło własnego podejścia do flory Paryża. Wybór opisywanych miejsc jest raczej nieprzypadkowy, ponieważ każde z nich obrosło w siatkę kulturowych odniesień. Tym samym projektowana autobiograficzność pozostaje dłużna częściowo jedynie prześwietlanym 
kliszom. Warto jednak odnotować różnicę w fokalizacji i przyjętej metodzie pisarskiej: jeśli Eveno koncentruje się, lub wręcz zatrzymuje, na doświadczeniu wzrokowym nieśpiesznego przechodnia i spacerowicza, postrzegającego rośliny w pozycji pionowej, Lacroix sytuuje swojego narratora w zgoła odmiennej pozycji:

Niewykluczone, że z inaczej ukształtowanym spojrzeniem, z innymi a priori, w pierwszej kolejności dostrzegalibyśmy w Paryżu jego wiejski charakter. Siedzę właśnie na kamiennym nadbrzeżu Sekwany, na wysokości quai du Louvre. Oczywiście jest ono wyłożone kamienną kostką brukową, jednak spomiędzy niej wyrasta meszek mchu o silnie jasnozielonym odcieniu, można wręcz odnieść wrażenie, że wydobywa się zeń jakaś wewnętrzna światłość. Bruk jest nierówny i wybrzuszony, podważają go korzenie stuletnich drzew. Nurt rzeki pode mną unosi kołyszące się w nim rośliny morskie. Naprzeciw mnie w rzekę wcina się skwer Vert-Galant, zarastają go wierzby płaczące, których rozczochrane czupryny powiewają na wietrze.

Co właściwie zmienia się w wyniku przyjęcia pozycji siedzącej? Po pierwsze, pole tego, co widziane - to już nie tylko horyzont, ale także otoczenie, które sprawia, że znajdujemy się nieco bardziej wewnątrz materialno-organicznego świata. Po drugie, zasób zmysłów uruchamianych do sondowania tego środowiska. Dzięki zmianie pozycji narrator może silniej odczuć wybrzuszenie podłoża, na którym siedzi, i zlokalizować jego przyczynę, poczuć wiatr i zapach rzeki, wreszcie wymacać wyrastającą między kamieniami odmianę mchu, a nawet dać się chwilowo jej oślepić. Dostrzega także rośliny z pozoru nieistotne, chociażby wspomniane mchy i porosty, a odgrywające przecież kluczową rolę w ekosystemie stolicy:

To do tej odmiennej lektury środowiska miejskiego przywykli specjaliści od flory: zielarze amatorzy lub profesorzy nauk o życiu. W 1866 roku botanik finlandzkiego pochodzenia, niejaki William Nylander, opublikował niewielki traktat zatytułowany Porosty ogrodu Luksemburskiego. Wyszczególniał w nim prawie trzydzieści trzy gatunki i trzy odmiany porostów. Trzydzieści lat później Nylander ponowił swoje badania, znacznie powiększając ich obszar. Wnioski, do których doszedł i które zaprezentował w Porostach regionu paryskiego, były niepokojące: gęsta zabudowa fabryczna nieużytkowanych terenów otaczających miasto spowodowała zniknięcie 
wszystkich zaobserwowanych przez niego wcześniej trzydziestu trzech gatunków. Fala drugiej rewolucji przemysłowej zdusiła roślinność stolicy. ${ }^{15}$

Zdaje się, że Lacroix wybiera ten aspekt środowiskowej historii Paryża nie bez powodu, lecz po to, by na przykładzie praktyki badawczej Nylendera i wpływu rewolucji przemysłowej na florę wykazać głęboką współzależność wszystkich elementów miejskiego ekosystemu. Jego wrażliwość ukształtował zaś zwrot, jaki dokonał się w humanistyce pod koniec ubiegłego wieku. W następujących słowach problem ujmował wówczas amerykański historyk Richard C. Foltz: „A przecież powinnyśmy pamiętać, że ludzie wchodzą w interakcje nie tylko ze sobą nawzajem, lecz również - wszędzie i zawsze - ze światem nie-ludzi. Wszelkie działania człowieka zachodzą w kontekście ekosystemów, które w różnym miejscu i czasie mają na nie najróżniejszy wpływ ${ }^{16}$ ". Jeszcze dobitniej wyraża dziś pokrewną myśl filozofka Lucy Irigaray. Sformułowana przez nią koncepcja ontologicznej relacyjności zakłada, że: „życia nigdy nie da się zredukować do «bytu» czy «obiektu». Możemy jedynie komunikować się i tworzyć wspólnotę poprzez nie. To przez tlen, jakiego dostarczają nam rośliny, przychodzimy na świat i możemy żyć dzięki oddychaniu. [...] świat roślin może działać jako żywy pośrednik [...]"17.Takim właśnie pośrednikiem między ludzkimi i nie-ludzkimi mieszkańcami stolicy Francji okazują się rośliny w ujęciu Lacroix:

Choć pasjonujące, to szczególne podejście do Paryża rozpatrywanego jako ekosystem zostało poniechane aż do czasu publikacji w roku 1948 rozprawy autorstwa Maurice'a Bouly de Lesdain zatytułowanej Ekologia (fanerofity-mchy-porosty) niektórych terenów Paryża. We wstępie do swego dzieła Bouly de Lesdain wyjaśnia wyjątkowe okoliczności, które doprowadziły go do podjęcia badań. Podczas okupacji zmuszony był do pobytu

Tamże, s. 198.

R.C. Foltz Czy przyroda jest sprawcza w znaczeniu historycznym? Historia świata, historia środowiska oraz to, w jaki sposób historycy moga pomóc ocalić Ziemię, przeł. A. Czarnacka, w: Teoria wiedzy o przeszłości na tle współczesnej humanistyki, red. E. Domańska, Wydawnictwo Poznańskie, Poznań 2010, s. 633.

17 Rozmowa z legendarnq filozofkq i aktywistkq̨: Luce Irigaray, przeł. K Szopa, „Nowa Orgia Myśli" 2017, http://nowaorgiamysli.pl/index.php/2017/11/16/rozmowa-z-legendarna-filozofka-i-aktywistka-luce-irigaray/ (03.01.2018, podkreślenia - redakcja NOM). 
w Paryżu. Ten pełen determinacji doktor postanowił wykorzystać przymusowe wakacje podarowane mu przez Historię do zbadania poszczególnych terenów: parku Monceau, cmentarza Montmartre, ogrodu botanicznego Jardin des Plantes, ogrodów Tuileries, a wreszcie nabrzeża Sekwany między mostami Grenelle i Bercy. ${ }^{18}$

Znamienny jest w tym kontekście także wybór bohaterów, czyli botaników prowadzących badania w czasie zawieruchy dziejowej, ale też trochę mimo niej. Dzięki zapośredniczeniu opowieści w konkretnej biografii narrator ulega w końcu, charakterystycznej dla technik pisania o roślinach, pokusie cytowania ich nazw własnych w oryginale:

Odnośnie do nadbrzeży nasz naukowiec podjął się wpierw identyfikacji różnych środowisk wspomagających wegetację. Tym samym schody, umacniające koryto rzeki i ścieżki do holowania, mury i podtrzymujące je parapety, wszystkie one tworzą stację wapienną, w której chronią się barbula muralis, bryum argentum, a nawet, nieco rzadziej, homalothecium sericeum. W tej roślinnej panoramie znajdują się także bardziej intymne zakątki, na przykład u podnóża murów [...] znaleźć można rośliny karłowate jak erigeon canadensis lub caloplaca inscrutus var. urbana z pięknymi złocistymi plechami. ${ }^{19}$

Warto zauważyć, że współczesna humanistyka ekologiczna, rozwijana chociażby w obrębie wspomnianej już historii środowiskowej, stawia sobie za cel zbadanie sprawczości nie-ludzkich podmiotów, w tym roślin, interpretuje także to, jak krajobraz reaguje na wydarzenia historyczne ${ }^{20}$. W efekcie: „zmienia się również sposób myślenia o samej przyrodzie. Przestaje być ona postrzegana wyłącznie jako bierne tło wydarzeń historycznych i zaczyna występować w roli sprawcy (agenta) historii człowieka"21. Ten aspekt jest równie silnie obecny u Lacroix, który skrupulatnie odnotowuje botaniczne ciekawostki z okresu II wojny światowej:

Tamże, s. 199.

Tamże, s. 199-200.

Zob. D. Beerling The Emerald Planet. How Plants Changed Earth's History, Oxford Univeristy Press, Oxford 2007; E. Domańska Humanistyka ekologiczna, "Teksty Drugie” 2013 nr 1/2, s. 13-32.

Nie-miejsca pamięci. Elementarz, red. R. Sendyka, Kraków 2017, s. 50. 
Dlaczego wiosną 1942 roku paulownie, rośliny ozdobne przeszczepione z Chin, obsypały się obfitym różowym kwieciem o niesłychanie intensywnym zapachu, na nigdy dotąd niespotykaną w naszych stronach skalę? Konsensus dotyczący tej drażliwej kwestii, który wypracowano w obrębie wspólnoty naukowej, brzmiał następująco: podczas okupacji ruch samochodowy uległ tak znacznemu zmniejszeniu, a zużycie węgla drzewnego na opał zmalało tak istotnie, że powietrze w mieście uwolniło się od zatruwających żywe organizmy gazów, a flora gwałtownie odżyła. ${ }^{22}$

W istocie, burzliwe wydarzenia historyczne, w poczet których można wpisać okupację niemiecką lub falę rewolucji kulturowej maja 1968 roku, modyfikują nie tylko przebieg życia codziennego, ale i ekosystem Paryża. Wstrzymanie ruchu samochodowego, a nade wszystko pracy pobliskich fabryk, chwilowo redefiniuje relacje miasta industrialnego i jego przyrody ${ }^{23}$. Opisywana zależność - dotycząca wpływu wydarzeń historycznych na warunki bytowania i rozwoju flory - sięga znacznie dalej. Te same paulownie, budzące zachwyt Ernsta Jüngera, okupanta przebywającego wówczas w Paryżu, postrzegane były jako przejaw niezwykłości tego okresu, urastając do rangi elementu opowieści czy wręcz mrocznej, miejskiej legendy. Paradoksalnie bowiem obsypany kwiatami, wypełniony samosiejkami Paryż okresu okupacji w oczach jego mieszkańców tracił swój metropolitalny charakter, ulegał równocześnie przemocy i prowincjonalizacji. Z jednej strony nazbyt bujna roślinność stanowiła widomy znak poniżenia, z drugiej natomiast, dzięki zaadministrowanej w mieście uprawie, pozwalała wzbogacić skromne racje żywieniowe. Ta powikłana relacja wydaje się pod wieloma względami symptomatyczna dla stosunku do flory miejskiej wyrażanego nie tylko przez pisarzy.

\section{Trzeci pejzaż, czyli postindustrialne chaszcze i podmiejskie eksploracje}

Dziennikarz i prozaik średniego pokolenia, Philippe Vasset, należy do tego samego grona pisarzy-podmiejskich eksploratorów co m.in. François Bon, François Maspero, Jacques Réda, Jean Rolin, Denis Tillinac ${ }^{24}$. Vasset jest au-

Voyage au centre..., s. 201.

Na temat tego drugiego epizodu piszę obszerniej w artykule Miejska fauna Claude'a Arnauda. O kontrkulturowej topografii literackiej Paryża lat7o. XX wieku, ,"Teksty Drugie” 2014 nr 6, s. 175.

4 Zob. F. Martin-Achard Des promenades dans cette épaisseur des choses reconstruites. Introduction au récit périurbain (Bon, Rolin, Vasset), ,'Comparaison. International Journal of Comparative 
torem wielu cenionych powieści, lecz największą popularnością cieszy się wydana przed dekadą Un livre blanc [Biała książka], stanowiąca część projektu „geografii równoległej”, w ramach której pisarz postanowił sprawdzić, co kryje się w miejscach oznaczonych na mapach jako białe plamy, współczesne terrae incognitae usytuowane zwykle na obrzeżach metropolii. W tym celu, przy użyciu oficjalnej kartografii ${ }^{25}$, postanowił przez rok eksplorować niezmapowane zakątki regionu paryskiego. Efektem prowadzonego przez niego śledztwa stała się książka i interaktywna mapa dostępne na stronie kolektywu. Pisarz opublikował następnie wskazówki dotyczące uprawianych przez niego praktyk, czyli rodzaj antyporadnika, który zamiast tradycyjnej, miejskiej przechadzki promuje raczej podmiejski rekonesans ${ }^{\mathbf{2 6}}$.

Opowieść Vasseta nie tylko zainspirowała wielu czytelników do podjęcia podobnych działań, ale i wpisała się w zyskujący popularność nurt eksploracji miejskiej. Urbex (ang. urban exploration), nazywany też speleologią lub archeologią miejską (ang. urban spelunking/archeology), łączy się z praktyką hackowania konkretnych typów przestrzeni, np. opuszczonych budynków (najczęściej użyteczności publicznej lub postindustrialnych, typu fabryki, koszary, szpitale, sanatoria, parki, silosy, składowiska), wreszcie dachów i kanałów, a także tuneli i katakumb27. Eksploratorzy miejscy próbują dostać

Literature" 2008 No. 1, S. 5-27; F. Zanghi Zone indécise : périphéries urbaines et voyage de proximité dans la littérature contemporaine, Presses Universitaires du Septentrion, Villeneuve d'Ascq, 2014; I. Porfido Un livre blanc de Philippe Vasset ou le silence des cartes, ,',Revue italienne d'études françaises" 2015 No. 5, http://journals.openedition.org/rief/1038, (20.11.2017); É. Colon Neither lieux de mémoire, nor non-lieux: toward a concept of precarious spaces in Philippe Vasset's Un livre blanc , „French Studies” 2017 No. 71, s. 66-83. Po drugiej stronie kanału La Manche podobne praktyki (pod)miejsko-literackie rozwijają m.in. pisarze lain Sinclair, Will Self i Robert MacFarlane, we Włoszech zaś chociażby Gabriella Kuruvila, a także Laboratorio di arte urbana Stalker/ Osservatorio nomade, co pozwala sformułować tezę o podmiejskiej eksploracji jako coraz popularniejszej praktyce kulturowej, współkonstytutywnej dla wyłaniającego się na przecięciu reportażu, eseju i prozy autobiograficznej nurtu literatury współczesnej, a zwłaszcza najnowszej. Martin-Achard nazywa ten typ pisarstwa opowieścią podmiejską lub literaturą in situ (fr. récit périurbain/littérature in situ), Dominique Viart natomiast literaturą terenową (fr. littérature de terrain), zob. D. Viart, B. Vercier La littérature française au présent. Héritage, modernité, mutations, Bordas, Paris 2005.

25 Autor wybrał szesnaście obszarów nieoznaczonych na mapie Paryża numer 2314 OT sporządzonej przez IGN (fr. Institut géographique national).

P. Vasset Pour en finir avec la promenade, w: Le grand Paris est un roman, dir. H. Bleskine, Éditions La Villette, Paris 2008, s. 61-64.

27 Zob. B. L. Garrett Explore Everything: Place-hacking the City, Verso Books, New York 2013, P. Dobraszczyk The Dead City: Urban Ruins and the Spectacle of Decay, I.B. Tauris, New York 2017. 
się do miejsc niezamieszkanych, nieużywanych, niszczejących czy wręcz popadających w ruinę, przede wszystkim wszak niewidocznych, słabo znanych lub po prostu opuszczonych i przez to zapomnianych, nad którymi władzę przejęła przyroda. Swoje wyczyny, które z zasady nie powinny pozostawiać śladów ani modyfikować zastanego stanu rzeczy, rejestrują za pomocą zdjęć lub notatek, niekiedy efektem podobnych wypraw stają się blogi, albumy fotograficzne, a także książki. W tej perspektywie interesująco wypada romantyczna topika ruin wchodząca $\mathrm{w}$ dialog z poetyką postapokaliptyczną, gdyż obydwie akcentują rolę roślin zarastających niegdysiejsze tereny zurbanizowane. Co ciekawe, tego typu miejsca stanowią również inspirację dla nowych rodzajów podejścia do miejskiej flory, redefiniują jej rolę i znaczenie dla ekosystemu, a przede wszystkim bioróżnorodności. Jak trafnie odnotowuje Kinga Zinowiec-Cieplik: „Lata 9o. XX wieku, z głośnymi rewitalizacjami wielkopowierzchniowych poprzemysłowych katastrof przyrodniczych, jak Park Krajobrazowy Duisburg Nord w zagłębiu Rurhy, czy Park Krajobrazowy Cospuden na południe od Lipska, jako prekursorzy, przygotowały grunt dla współczesnych zielonych idei ${ }^{28 "}$.

Narrator Un livre blanc wchodzi w kontakt z florą i fauną paryskich peryferii, wielokrotnie podczas swoich wypraw doświadcza jej różnorodności, istotne wydaje się tu - charakterystyczny dla całej podmiejskiej biosfery element zaskoczenia, nieprzewidywalności, a także oporu stawianego przez nie-ludzkie podmioty:

Teren, graniczący od północy ze strefą przemysłową regionu Val-de-Seine, od południa z autostradą 86 i od wschodu z linią kolejową RER C, jest zupełnie dziki; zarastające go chwasty sięgają mi do ramion, są tu wysuszone bagna i kępy trzciny. Podczas mojej pierwszej wizyty stanąłem

W kontekście Urbexu obserwować możemy procesy, które zachodzą w odniesieniu do sporej części poszczególnych niecodziennych praktyk miejskich. O ile początkowo są one udziałem nielicznej grupy wtajemniczonych, amatorów, często również artystów, członków grup awangardowych lub kontrkulturowych (za przykład niech posłuży psychogeografia i dryf uprawiany przez Sytuacjonistów, ale również graffiti), o tyle stopniowo przeradzają się w coraz bardziej popularne hobby, a na końcu zostają przejęte przez przemysł turystyczny oferujący chociażby wycieczki do miejsc opuszonych, eksploracje dzielnic biedy, stref skażonych itd. W ten sposób wyłoniła się m.in. czarna turystyka (ang. dark tourism).

28 K. Zinowiec-Cieplik Nowoczesna natura we współczesnym mieście, "Zeszyty Naukowe Uczelni Vistula" 2017 nr 53, s. 177. Autorka artykułu używa określenia "roślinność spontaniczna" (ang. spontaneous vegetation), choć być może bardziej adekwatne byłoby istniejące wyrażenie „,roślinność samorzutna". 
nawet oko w oko z lisem (to on czmychnął jako pierwszy). Z roślinnej gęstwiny wyłaniają się jedynie jasnożółte paliki podtrzymujące dwuspadowy daszek, które miarowo znaczą przebieg podziemnych gazociągów wysokiego ciśnienia. Teren przecina parę ścieżek, które jednak urywają się nagle niczym pas wykładziny i dalej trzeba przedzierać się przez krzewy jeżynowe. ${ }^{29}$

Opisane w prozie Vasseta rośliny nie stanowią ani przemyślnej ozdoby, ani intruza. One po prostu istnieją i to na takich samych prawach jak każdy inny element biosfery wpływającej na kształt miasta w procesie, którego kłącza rozciągają się daleko poza granice bulwaru peryferyjnego Paryża. Co więcej, obecność „,dzikich chaszczy” pozwala narratorowi przedefiniować zakres semantyczny metropolii. Eksplorowane przez Vasseta tereny niezmapowane to nie tyle suburbia, ile część samego miasta, jego heterogenicznej struktury, której najsłabiej zbadane elementy pobudzają jedynie potrzebę doświadczania przygody.

Ingo Kowarik, badający zadrzewienia pojawiające się na terenach silnie zurbanizowanych (głównie w obrębie pozostałości postindustrailnych), argumentuje na rzecz rozważnej integracji nowoczesnych ekosystemów z systemami zielonej infrastruktury, która uwzględniałaby zarówno estetyczne potrzeby mieszkańców, jak i historyczne i socjo-ekonomiczne uwarunkowania danego miasta ${ }^{30}$. Z kolei Peter Del Tredici dzikie rośliny obszarów zurbanizowanych nazywa roślinami kosmopolitycznymi ${ }^{31}$. Badacz zwraca uwagę na interesujący fakt, który niekiedy umyka naszej uwadze, a mianowicie na znaczące różnice w podejściu do tych samych gatunków roślin uwarunkowane wyłącznie zmiennym kontekstem ich występowania: „Wielu mieszkańców miast interpretuje obecność rośliności samorzutnej w ich sąsiedztwie jako przejaw degradacji i zaniedbania, nawet jeśli te same rośliny występujące na przedmieściach lub na wsi mogliby postrzegać jako „,dzikie kwiaty”. Tym samym, kontekst występowania roślin w istotnym stopniu wpływa na sposób, w jaki je postrzegamy ${ }^{32}$.

29 P. Vasset Un livre blanc, Fayard, Paris 2007, s. 27.

Wild Urban Woodlands, eds. I. Kowarik, S. Körner, Springer, Berlin 2005.

P. Del Tredici The Flora of the Future. Celebrating the botanical diversity of cities, „Places: Journal” 2014 No. 4. re and Culture" 2010 No. 5, s. 309 [przekład własny - C.Z.]. 
Jeszcze większym orędownikiem roślin kosmopolitycznych i samorzutnych wydaje się autor koncepcji Trzeciego Pejzażu, francuski botanik i ekoteoretyk, Gilles Clément. Jak twierdzi:

Gdy tylko przestajemy postrzegać pejzaż jako przedmiot przemysłu, odkrywamy nagle - czy chodzi o przeoczenie kartografa, zaniedbanie polityka? - mrowie miejsc nieokreślonych, pozbawionych funkcji, którym trudno nadać nazwę. Jest to konglomerat, którego nie można przypisać ani do terytorium cienia, ani do terytorium światła. Sytuuje się na marginesach. Na skraju lasów, wzdłuż dróg i brzegów rzek, w zapomnianych zakątkach kultury, tam, gdzie nie docierają maszyny. Pokrywa powierzchnie nieznacznych rozmiarów, rozproszone niczym zacierające się końce pola, jednolite i rozlegle niczym torfowiska, wrzosowiska, tereny, na których niedawno poniechano uprawy. Między tymi fragmentami pejzażu nie zachodzi żadne podobieństwo formy. Jedyny punkt wspólny: ich terytorium stanowi schronienie dla - zewsząd wygnanej - bioróżnorodności. Dla tego powodu możemy określić te miejsca za pomocą jednego terminu. Proponuję pojęcie Trzeciego Pejzażu. ${ }^{33}$

Idee wyłożone przez Clémenta, akcentujące zwłaszcza pozytywne aspekty roślinności uważanej dotychczas za niepożądany i eliminowany komponent flory niebędącej częścią miejskich systemów zielonych, bez wątpienia znajdują swoje literackie rozwinięcie w utworach Vasseta i pokrewnych pisarzy-eksploratorów. Zarówno Clément, jak i autor Un livre blanc zwracają uwagę na konieczność współbycia mieszkańców i nie-ludzkich aktorów wynikającą z uwikłania w sieć wzajemnych zależności. Jak zauważa botanik, określenie „środowisko" (fr. environnement) denotuje otoczenie, czyli to, co znajduje się wokół lub też obok człowieka, natomiast w rzeczywistości stanowimy część ekosystemu. Właściwiej byłoby zatem mówić o stanie przynależności lub zanurzenia.

Koncepcja Trzeciego Pejzażu jest wyraźnie polemiczna wobec założeń architektury krajobrazu, odbiega również od antropologii pustych przestrzeni ${ }^{34}$ w tym stopniu, w jakim kwestionuje zasadność tego określenia. Przyroda nie znosi próżni, a nieużytki, tereny niezabudowane, postindustrialne lub nie-

G. Clément Manifeste du Thiers paysage, Éditions Sujet/Objet, Paris 2004, s. 4.

34 J. Kociatkiewicz, M. Kostera Antropologia pustych przestrzeni, w: Pisanie miasta - czytanie miasta, red. A. Zeidler-Janiszewska, Wydawnictwo Fundacji „Humaniora”, Poznań 1997. 
zmapowane obszary miasta w rzeczywistości wcale nie są puste, choć niejednokrotnie naruszają horyzont oczekiwań jego mieszkańców ${ }^{35}$. Szczególnego rodzaju świadectwa na temat zmian zachodzących w podejściu do miejskiej flory, ale też różnorodności postaw i praktyk z nią związanych dostarcza zatem twórczość pisarzy, którzy potrafią dostrzec i literacko zobrazować kulturową sprawczość roślin.

\section{Abstract}

\section{Clara Zgoła}

CRAL CNRS-EHESS

UNIVERSITY OFWARSAW

The Plant History of the City as Seen by an Inhabitant

Based on the work of contemporary autobiographical fiction by Claude Eveno, Alexandre Lacroix and Philippe Vasset, Zgoła reads the plant history of Paris as seen by its inhabitants. She examines the cultural agency of the city's flora in the twentieth and twenty-first centuries from a historical and anthropological perspective, and she contextualizes her analysis with theoretical concepts developed by Gilles Clément (the third landscape), Peter del Tredici (cosmopolitan urban meadow) and Bradley L. Garrett (urban exploration). Tracing the role of socially sanctioned forms of organizing urban green spaces as well as related vernacular and experimental practices, Zgoła shows how different types of interaction with the botanic environment go hand in hand with a separate repertoire of urban practices as well as literary ways of representing them.

\section{Keywords}

urban vegetation, urbex, French literature

35 Nature en ville. Désirs \& controverses, dir. L. Bourdeau-Lepage, La librairie des territoires, Lyon 2018. 